(c) American Dairy Science Association, 2006.

\title{
Ceftiofur Derivatives in Serum, Uterine Tissues, Cotyledons, and Lochia after Fetal Membrane Retention
}

\author{
M. Drillich, ${ }^{\star 1}$ S. Arlt, ${ }^{\star}$ S. Kersting, ${ }^{\star}$ A. A. Bergwerff, $†$ P. Scherpenisse, $\dagger$ and W. Heuwieser ${ }^{\star}$ \\ ${ }^{*}$ Clinic for Reproduction, Faculty of Veterinary Medicine, Free University of Berlin, Königsweg 65, D-14163 Berlin, Germany \\ †Division of Public Health and Food Safety, Institute for Risk Assessment Sciences, Faculty of Veterinary Medicine, \\ Utrecht University, P.O. Box 80.175, NL-3508 TD, Utrecht, the Netherlands
}

\section{ABSTRACT}

The objective of the study was to determine concentrations of ceftiofur derivatives after subcutaneous application of ceftiofur hydrochloride in cows with retained fetal membranes. Concentrations of ceftiofur derivatives detected as desfuroylceftiofuracetamide were determined in blood serum, endometrium, caruncles, cotyledons, and lochia during $72 \mathrm{~h}$. After induction of parturition, 2 primiparous and 4 multiparous cows having retained fetal membranes for at least $12 \mathrm{~h}$ were studied. All cows received 3 consecutive injections (C1 to $\mathrm{C} 3 ; 24 \mathrm{~h}$ apart) of $1-\mathrm{mg}$ ceftiofur equivalents per kilogram of body weight as ceftiofur hydrochloride sterile suspension. Samples of blood, endometrium, caruncles, cotyledons, and lochia were collected immediately before each injection $(0 \mathrm{~h})$ and again at 4,12 , and $24 \mathrm{~h}$ after C1, C2, and C3. Blood samples were collected from coccygeal vessels. Caruncles were removed from the uterine lumen by manual extirpation and separated from cotyledons. Endometrial tissue $(0.5 \mathrm{~g})$ was collected by using Kenny's biopsy apparatus. For all samples, concentrations of potentially active ceftiofur derivatives were quantified using an HPLC assay. Within 2 $\mathrm{h}$ (serum), $4 \mathrm{~h}$ (endometrium), and $12 \mathrm{~h}$ (caruncles, cotyledons, lochia) after $\mathrm{C} 1$ and during the entire study period, mean concentration of ceftiofur derivatives exceeded the reported minimum drug concentrations required to inhibit the growth of $90 \%$ of isolates for relevant bacteria such as Escherichia coli, Fusobacterium necrophorum, and Arcanobacterium pyogenes. Only in single samples did concentrations decrease temporarily below the reported minimum drug concentrations required to inhibit the growth of $90 \%$ of isolates.

Key words: retained fetal membrane, ceftiofur

\section{INTRODUCTION}

Cephalosporins are an important class of antimicrobial agents in use today for humans and animals (Hor-

Received February 2, 2006.

Accepted April 18, 2006.

${ }^{1}$ Corresponding author: author@bestandsbetreuung.de nish and Kotarski, 2002). The third-generation cephalosporin ceftiofur has been developed exclusively for veterinary use. Ceftiofur is approved for treatment of respiratory diseases in ruminants, swine, and horses and for foot rot and acute postpartum metritis in cattle. In Europe, ceftiofur is approved for treatment of acute postpartum metritis during the first $10 \mathrm{~d}$ postpartum at a dosage of $1 \mathrm{mg} / \mathrm{kg}$ of BW, whereas in the United States it is approved at a dosage of $2.2 \mathrm{mg} / \mathrm{kg}$ of BW. The recommended treatment period is 5 consecutive days. Clinical efficacy of a systemic antibiotic treatment with ceftiofur in cows with acute metritis (Smith et al., 1998; Drillich et al., 2001; Zhou et al., 2001; Chenault et al., 2004) and retained fetal membranes (Risco and Hernandez, 2003; Drillich et al., 2003, 2006a,b) has been demonstrated. Common bacteria involved in postpartum uterine diseases are Escherichia coli, Arcanobacterium pyogenes, and anaerobic species (e.g., Fusobacterium necrophorum and Prevotella species; Sheldon and Dobson, 2004). The clinical findings in cows with retained fetal membranes (RFM) are similar to findings in cows with acute metritis (i.e., increased rectal temperature and fetid vaginal discharge). Therefore, it can be assumed that in most instances RFM is associated with acute metritis.

Although early postpartum use of ceftiofur has been described in several studies, there is only limited information about the pharmacokinetics of ceftiofur in bovine uterine tissue. Pharmacokinetics and bioequivalence of ceftiofur in plasma have been compared for intramuscular and subcutaneous administration (Brown et al., 2000). Previous authors suggested similar therapeutic efficacy for the 2 routes of administration. The in vitro metabolism from ceftiofur to desfuroylceftiofur in bovine kidney, lung, liver, and muscle has been described (Olson et al., 1998). Okker et al. (2002) presented the pharmacokinetics of ceftiofur in plasma, lochia, and uterine tissues of 4 healthy cows. Data were collected during $24 \mathrm{~h}$ after a single subcutaneous administration of $1 \mathrm{mg} / \mathrm{kg}$ of ceftiofur. Concentrations of ceftiofur derivatives in uterine tissues exceeded the reported minimum drug concentrations required to inhibit the growth of $90 \%$ of isolates ( $\mathbf{M I C}_{\mathbf{9 0}}$ ) of $0.5 \mu \mathrm{g} /$ 
mL for E. coli (Cervantes et al., 1993; Salmon et al., 1996; Sheldon et al., 2004) and of $0.125 \mu \mathrm{g} / \mathrm{mL}$ for $A$. pyogenes, $F$. necrophorum, and Prevotella melaninogenicus (Sheldon et al., 2004). Okker et al. (2002) hypothesized that concentrations of ceftiofur would be greater in cows having acute metritis than in the healthy cows included in their study. This hypothesis is based on findings that ceftiofur accumulates in bacterially induced inflammatory sites (Clarke et al., 1996).

The objective of the present study was to determine concentrations of ceftiofur derivatives in serum, endometrium, caruncles, cotyledons, and lochia of cows having RFM during $72 \mathrm{~h}$ after treatment.

\section{MATERIALS AND METHODS}

\section{Experimental Design}

The study was conducted between February and September 2004 at the Clinic for Reproduction, Faculty of Veterinary Medicine, Free University of Berlin, Germany. Cows were housed at the clinic in a tie-stall barn with straw bedding. Parturition was induced between 270 and $280 \mathrm{~d}$ of gestation by using dexamethasone (4 $\mathrm{mg} / 100 \mathrm{~kg}$ of estimated BW, Dexasel, Selectavet, Otto Fischer, Weyarn-Holzolling, Germany). A total of 6 Holstein-Friesian cows (2 primiparous and 4 multiparous) having RFM for more than $12 \mathrm{~h}$ were studied. Average time from parturition to enrollment was $24.8 \mathrm{~h}$ (minimum $=12 \mathrm{~h}$; maximum $=43 \mathrm{~h}$ ).

During $14 \mathrm{~d}$ before calving and until the end of the study period, none of the cows included in the study received antimicrobial or antiinflammatory drugs other than ceftiofur hydrochloride. Study period was defined as the time from between collection of the first sample until collection of the last sample, $24 \mathrm{~h}$ after the third of 3 daily injections of ceftiofur.

Ceftiofur (Excenel RTU, Pfizer Animal Health, Karlsruhe, Germany) was administered subcutaneously in the neck region at a dosage of $1 \mathrm{mg}$ of ceftiofur equivalents $/ \mathrm{kg}$ of estimated BW as ceftiofur hydrochloride sterile suspension. A new vial was opened for each cow entering the study. Cows received ceftiofur on 3 successive days between 0800 and 0900 h (C1, C2, and C3, respectively). Rectal body temperature was measured in all cows immediately before collection of samples.

Baseline samples $(0 \mathrm{~h})$ were collected immediately before each injection of ceftiofur hydrochloride (C1). Additional samples were collected 2, 4, 12, and $24 \mathrm{~h}$ after $\mathrm{C} 1, \mathrm{C} 2$, and $\mathrm{C} 3$. For each cow and at each time point, first blood and then lochia, placentomes, and endometrial tissue were collected.

\section{Methods of Sampling}

Blood samples were collected from coccygeal vessels in sterile vacuum tubes (Venoject, Terumo Europe N.V., Leuven, Belgium). Thereafter, samples were stored for a maximum of $4 \mathrm{~h}$ at $4^{\circ} \mathrm{C}$ and centrifuged at 3,500 $\times \mathrm{g}$ for $10 \mathrm{~min}$ at $4^{\circ} \mathrm{C}$. Serum was stored at $-20^{\circ} \mathrm{C}$ in 2 aliquots of 2 to $3 \mathrm{~mL}$ each until analysis. Before collection of samples from the uterus, the perineum and vulva were cleaned with a paper towel. Thereafter, one sterile-gloved hand was introduced through the vagina into the uterine lumen and collected at least $15 \mathrm{~mL}$ of lochia. Samples were collected into 20 -mL plastic tubes. After sampling of lochia, one placentome was removed manually from the uterus. Once excised, cotyledons were carefully separated from the caruncles. Cotyledons and caruncles were cleaned and dried with a towel and stored in a plastic tube. Finally, endometrial tissue was sampled by Kenny's biopsy apparatus, which was introduced and guided by hand into the uterus. For each sample, approximately $0.5 \mathrm{~g}$ of endometrial tissue was collected, dried, and stored in plastic tubes. All samples of uterine tissues, cotyledons, caruncles, and lochia were stored immediately after sampling at $4^{\circ} \mathrm{C}$ for a maximum of $4 \mathrm{~h}$ before they were frozen and stored at $-20^{\circ} \mathrm{C}$ until analysis.

From one additional cow having RFM, but not treated with ceftiofur hydrochloride nor any other antibiotic, $40 \mathrm{~mL}$ of serum; $40 \mathrm{~mL}$ of lochia, caruncular, and cotyledonal tissue; and $5 \mathrm{~g}$ of endometrium were collected 24 $\mathrm{h}$ after calving as blank material for HPLC analysis.

\section{Analytical Methods}

Concentrations of ceftiofur residues were determined in caruncles, endometrium, and serum (Okker et al., 2002). In this method, residues of ceftiofur, including metabolites as desfuroylceftiofur-protein conjugates, are converted into desfuroylceftiofuracetamide (DCA), which was determined by HPLC. In brief, $1 \mathrm{~mL}$ of serum or lochia, or $0.5 \mathrm{~g}$ of endometrium, caruncles, orcotyledons were mixed with $5 \mathrm{~mL}$ of $50 \mathrm{~m} M$ potassium tetraborate (Merck, Darmstadt, Germany) at pH 9.0, containing $0.5 M$ sodium chloride (Merck) and $130 \mathrm{mM}$ dithioerythritol (Sigma-Aldrich, Zwijndrecht, the Netherlands), and incubated at $50^{\circ} \mathrm{C}$ for 15 min with intermittent mixing at 5 -min intervals. Following this reduction, $5 \mathrm{~mL}$ of $0.1 \mathrm{M}$ ammonium acetate (J.T. Baker, Deventer, the Netherlands) containing $0.2 \mathrm{M}$ iodoacetamide (Sigma-Aldrich) was added, mixed, and the incubation was continued in the dark at ambient temperature for $30 \mathrm{~min}$ under gentle agitation at $500 \mathrm{rpm}$. Homogenized lochia, carcuncles, cotyledons, and endometrium were acidified to $\mathrm{pH} 3$ with $0.08 \mathrm{~mL}$ of $17 \%$ phosphoric acid. After centrifugation at $4,000 \times g$ for 


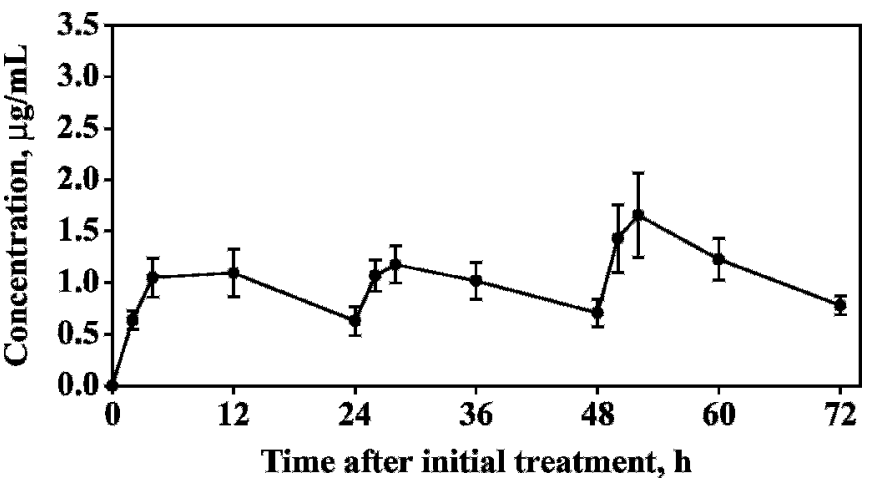

Figure 1. Mean concentrations $( \pm S E M)$ of desfuroylceftiofuracetamide in serum after 3 subcutaneous administrations of $1 \mathrm{mg}$ of ceftiofur equivalents $/ \mathrm{kg}$ of $\mathrm{BW}$ of ceftiofur hydrochloride sterile suspension at 0,24 , and $48 \mathrm{~h}$.

$30 \mathrm{~min}$ at $5^{\circ} \mathrm{C}$, the $\mathrm{pH}$ of the supernatant was adjusted to $\mathrm{pH} 5$ with approximately $0.1 \mathrm{~mL}$ of $5 \mathrm{M}$ sodium hydroxide and was then passed through a Bond Elut $\mathrm{C}_{18}$ - solid-phase extraction (SPE) cartridge ( $1 \mathrm{~g}$; Varian, Bergen op Zoom, the Netherlands). Cartridges were washed with $5 \mathrm{~mL}$ of $0.1 \mathrm{M}$ ammonium acetate and 5 $\mathrm{mL}$ of $2 \%$ (vol/vol) acetic acid, and then eluted with 5 $\mathrm{mL}$ of a mixture of acetonitrile (J.T. Baker) and $2 \%$ ( $\mathrm{vol} / \mathrm{vol})$ acetic acid (Merck) at a ratio of 2:8 ( $\mathrm{vol} / \mathrm{vol})$. Before their use, columns were activated with $5 \mathrm{~mL}$ of methanol and conditioned with $5 \mathrm{~mL}$ of $0.1 \mathrm{M}$ ammonium acetate solution (J.T. Baker).

Analyte-containing C18-SPE eluates were passed over a cation exchanger SCX SPE column (100 mg; Varian), which was then washed with $1 \mathrm{~mL}$ of methanol. Retained DCA was eluted with $1.0 \mathrm{~mL}$ of a mixture of 1.0 $\mathrm{M}$ ammonium acetate and acetonitrile at a ratio of 85:15 ( $\mathrm{vol} / \mathrm{vol})$. Before their use, the SCX cartridges were activated with $0.2 \mathrm{~mL}$ of methanol and conditioned with $2 \mathrm{~mL}$ of $2 \%(\mathrm{vol} / \mathrm{vol})$ acetic acid (Merck) in water, respectively.

The HPLC analysis of $50-\mu \mathrm{L}$ samples was carried out on a 3 - $\mu \mathrm{m}$ C18 column $(50 \times 4.6 \mathrm{~mm}$; Phenomenex, Torrance, CA) and a $3-\mu \mathrm{m}$ phenyl-hexyl $(50 \times 4.6 \mathrm{~mm}$; Phenomenex) column that were connected in line. Elution of analytes was performed using a binary linear gradient of $10 \mathrm{~m} M$ ammonium acetate at $\mathrm{pH} 6.8$ (eluent A) and acetonitrile (eluent B) at a flow rate of $1.0 \mathrm{~mL} /$ min as follows: $99 \% \mathrm{~A}$ (vol/vol) for $1.9 \mathrm{~min}$, to $92 \% \mathrm{~A}$ (vol/vol) in $0.1 \mathrm{~min}$, to $82 \% \mathrm{~A}$ ( $\mathrm{vol} / \mathrm{vol}$ ) in $12 \mathrm{~min}$, and to $0 \% \mathrm{~A}$ for $7 \mathrm{~min}$. The eluate was monitored at $266 \mathrm{~nm}$. Sample series were analyzed with a repetitive analysis time of 30 min per sample. Limit of quantification of the method was $0.1 \mu \mathrm{g} / \mathrm{mL}$ of ceftiofur for lochia and serum and $0.1 \mu \mathrm{g} / \mathrm{g}$ of ceftiofur for caruncles, cotyledons, and endometrium. Standards were prepared from

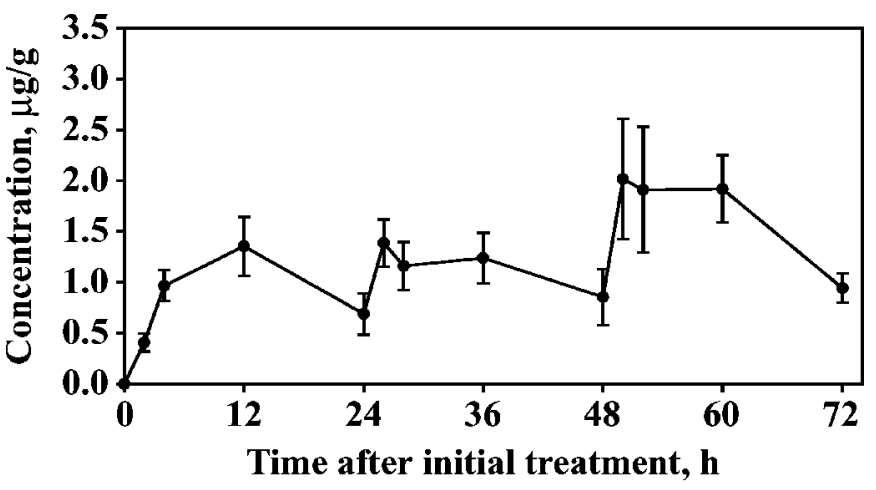

Figure 2. Mean concentrations $( \pm \mathrm{SEM})$ of desfuroylceftiofuracetamide in endometrial tissue after 3 subcutaneous administrations of $1 \mathrm{mg}$ of ceftiofur equivalents/kg of BW of ceftiofur hydrochloride sterile suspension at 0,24 , and $48 \mathrm{~h}$.

blank corresponding biological materials spiked at 8 different concentration points between 0.1 and $10 \mu \mathrm{g} /$ $\mathrm{mL}(\mu \mathrm{g} / \mathrm{g}$ ) of ceftiofur (Pfizer Animal Health, Puurs, Belgium) and then processed and analyzed simultaneously and in an identical way as the laboratory samples. Standards were used to obtain a standard curve following linear regression analysis. In fact, the standard curve was used as a control of the quality of the analysis procedure.

\section{Interpretation and Analyses}

When concentrations of DCA were greater than the standard of $10 \mu \mathrm{g} / \mathrm{mL}(\mu \mathrm{g} / \mathrm{g})$, these samples were reanalyzed, and when values were reproducible, they were regarded as outliers. In these cases, values were excluded from analyses.

Concentrations of DCA of $\geq 0.5 \mu \mathrm{g} / \mathrm{mL}$ or $\geq 0.5 \mu \mathrm{g} / \mathrm{g}$ and of $\geq 0.125 \mu \mathrm{g} / \mathrm{mL}$ or $\geq 0.125 \mu \mathrm{g} / \mathrm{g}$ are relevant for the potential efficiency of a treatment against $E$. coli and $A$. pyogenes, and $F$. necrophorum and $P$. melaninogenicus, respectively (Cervantes et al., 1993; Salmon et al., 1996; Sheldon et al., 2004). Therefore, these concentrations were regarded as threshold values.

Correlation of time after $\mathrm{C} 1$, temperature, and concentration of DCA in serum with concentrations of DCA in serum, endometrium, caruncles, cotyledons, and lochia was tested by using Spearman's rank correlation for nonparametric variables (SPSS for Windows 12.0, SPSS Inc., Munich, Germany). Samples collected before the first of 3 injections of ceftiofur hydrochloride were excluded from these analyses. Level of significance was set at $\alpha=0.05$.

\section{RESULTS}

Described analytical methods were found to be suitable for determining DCA in described bovine materials 
Table 1. Numbers of samples with concentrations of desfuroylceftiofuracetamide (DCA) $<0.5$ and $0.125 \mu \mathrm{g} /$ $\mathrm{mL}$ (serum and lochia) or 0.5 and $0.125 \mu \mathrm{g} / \mathrm{g}$ (endometrium, caruncles, and cotyledons) after 3 subcutaneous administrations ( $24 \mathrm{~h}$ apart) of $1 \mathrm{mg}$ of ceftiofur equivalents per $\mathrm{kg}$ of BW as ceftiofur hydrochloride sterile suspension

\begin{tabular}{|c|c|c|c|c|c|c|c|c|c|c|c|c|c|c|}
\hline \multirow[b]{2}{*}{ Tissue } & \multirow{2}{*}{$\begin{array}{l}\text { Concentration } \\
\text { of } \\
\mathrm{DCA}^{2}\end{array}$} & \multicolumn{13}{|c|}{ Time of sampling after first of 3 injections, ${ }^{1} \mathrm{~h}$} \\
\hline & & 0 & 2 & 4 & 12 & 24 & 26 & 28 & 36 & 48 & 50 & 52 & 60 & 72 \\
\hline \multirow[t]{2}{*}{ Serum } & $<0.5$ & $6 / 6$ & $2 / 6$ & - & - & $2 / 6$ & - & - & - & $3 / 6$ & - & - & - & - \\
\hline & $<0.125$ & $6 / 6$ & - & - & - & - & - & - & - & - & - & - & - & - \\
\hline \multirow{2}{*}{ Lochia } & $<0.5$ & $6 / 6$ & $4 / 6$ & $4 / 6$ & $4 / 6$ & $5 / 6$ & $5 / 6$ & $2 / 6$ & $3 / 6$ & $2 / 5$ & $4 / 5$ & $3 / 5$ & $1 / 5$ & $2 / 5$ \\
\hline & $<0.125$ & $6 / 6$ & $4 / 6$ & - & - & - & $1 / 6$ & $1 / 6$ & - & - & $1 / 5$ & - & - & $1 / 5$ \\
\hline \multirow[t]{2}{*}{ Endometrium } & $<0.5$ & $6 / 6$ & $4 / 6$ & - & - & $2 / 6$ & - & $1 / 6$ & - & $1 / 5$ & - & - & - & - \\
\hline & $<0.125$ & $6 / 6$ & $1 / 6$ & - & - & $1 / 6$ & - & - & - & $1 / 5$ & - & - & - & - \\
\hline \multirow[t]{2}{*}{ Caruncle } & $<0.5$ & $6 / 6$ & $6 / 6$ & $5 / 6$ & - & $1 / 6$ & - & - & - & $1 / 6$ & - & - & $1 / 6$ & - \\
\hline & $<0.125$ & $6 / 6$ & $1 / 6$ & - & - & - & - & - & - & - & - & - & - & \\
\hline \multirow[t]{2}{*}{ Cotyledon } & $<0.5$ & $6 / 6$ & $5 / 6$ & $4 / 6$ & - & - & - & - & - & $2 / 6$ & - & $1 / 6$ & $1 / 5$ & $1 / 3$ \\
\hline & $<0.125$ & $6 / 6$ & $1 / 6$ & - & - & - & - & - & - & - & - & - & - & - \\
\hline
\end{tabular}

${ }^{1}$ Fields without numbers indicate that all samples exceeded reference concentrations.

${ }^{2}$ For serum and lochia, concentrations are in $\mu \mathrm{g} / \mathrm{mL}$; for endometrium, caruncle, and cotyledon tissues, concentrations are in $\mu \mathrm{g} / \mathrm{g}$.

because the coefficients of determination of standard curves were better than $0.9994(\mathrm{n}=12)$. Only once was this coefficient less than $<0.0994$ (0.991 for endometrium). The interday variance of the slopes of the curves did not vary more than $15 \%$ in most cases, indicating acceptable reproducibility of the test results. Outliers were found in 4 ( 2 in serum, 1 in caruncular tissue, and 1 in lochia) of 381 analyzed samples, and those values were excluded from further analyses.

\section{Serum}

A total of 78 samples were analyzed for concentrations of DCA in serum. Mean concentration reached $0.64 \mu \mathrm{g} / \mathrm{mL}$ at $2 \mathrm{~h}$ and remained above the threshold value of $0.5 \mu \mathrm{g} / \mathrm{mL}$ during the entire observation period. A maximum mean concentration during the collection period before a subsequent administration of ceftiofur was reached at $12(1.10 \mu \mathrm{g} / \mathrm{mL}), 4(1.18 \mu \mathrm{g} / \mathrm{mL})$, and $4(1.66 \mu \mathrm{g} / \mathrm{mL}) \mathrm{h}$ after $\mathrm{C} 1, \mathrm{C} 2$, and $\mathrm{C} 3$, respectively (Figure 1).

Concentrations increased in all cows above the threshold value of $0.125 \mu \mathrm{g} / \mathrm{mL}$ by $2 \mathrm{~h}$ and above 0.5 $\mu \mathrm{g} / \mathrm{mL}$ by $4 \mathrm{~h}$ after the initial injection of ceftiofur hydrochloride. In 2 samples, however, concentrations decreased to $<0.5 \mu \mathrm{g} / \mathrm{mL}$ at $24 \mathrm{~h}$ (i.e., immediately before $\mathrm{C} 2$ ), and in 3 samples immediately before C3 (Table 1). Maximum concentration in a single sample was 3.25 $\mu \mathrm{g} / \mathrm{mL}$.

\section{Endometrial Tissue}

Endometrial tissue was analyzed in 78 samples. Within $4 \mathrm{~h}$ after $\mathrm{C} 1$ and until the end of the observation period, mean concentration of DCA exceeded the threshold value of $0.5 \mu \mathrm{g} / \mathrm{g}$. Mean concentration of 0.125 $\mu \mathrm{g} / \mathrm{g}$ was reached at $2 \mathrm{~h}$. Maximum mean concentrations in endometrial tissue were found at $12 \mathrm{~h}(1.35 \mu \mathrm{g} /$ $\mathrm{g}), 2 \mathrm{~h}(1.39 \mu \mathrm{g} / \mathrm{g})$, and $2 \mathrm{~h}(2.02 \mu \mathrm{g} / \mathrm{g})$ after $\mathrm{C} 1, \mathrm{C} 2$, and C3, respectively (Figure 2). After $2 \mathrm{~h}$, concentrations decreased to $<0.5 \mu \mathrm{g} / \mathrm{g}$ were found in 4 samples and $<0.125 \mu \mathrm{g} / \mathrm{g}$ in 2 samples (Table 1 ).

\section{Caruncular Tissue}

Mean concentrations of DCA above the threshold value of $0.125 \mu \mathrm{g} / \mathrm{g}$ were reached at $2 \mathrm{~h}$, and greater than $0.5 \mu \mathrm{g} / \mathrm{g}$ at $12 \mathrm{~h}$ after $\mathrm{C} 1$. Mean concentration remained above $0.5 \mu \mathrm{g} / \mathrm{g}$ until the end of the observation period. A maximum in mean concentrations was found at $12 \mathrm{~h}(1.03 \mu \mathrm{g} / \mathrm{g}), 12 \mathrm{~h}(1.95 \mu \mathrm{g} / \mathrm{g})$, and $4 \mathrm{~h}(2.36 \mu \mathrm{g} /$ g) after $\mathrm{C} 1, \mathrm{C} 2$, and $\mathrm{C} 3$, respectively (Figure 3). In 1 cow, concentrations of DCA decreased to $<0.5 \mu \mathrm{g} / \mathrm{g}$ at 24 and 48 h (i.e., immediately before $\mathrm{C} 2$ and C3, and again at $60 \mathrm{~h}$ ).

\section{Cotyledonal Tissue}

Cotyledonal tissue could not be obtained from 1 cow at 60 and $72 \mathrm{~h}$ and could not be obtained from 2 other cows at $72 \mathrm{~h}$. Mean concentrations of DCA exceeded $0.125 \mu \mathrm{g} / \mathrm{g}$ at $2 \mathrm{~h}$ and $0.5 \mu \mathrm{g} / \mathrm{g}$ at $12 \mathrm{~h}$ after $\mathrm{C} 1$ and until the end of the observation period. A maximum in mean concentrations of DCA in cotyledonal tissue was found at $24 \mathrm{~h}(1.75 \mu \mathrm{g} / \mathrm{g}), 12 \mathrm{~h}(2.14 \mu \mathrm{g} / \mathrm{g})$, and $2 \mathrm{~h}(2.56$ $\mu \mathrm{g} / \mathrm{g}$ ) after C1, C2, and C3, respectively (Figure 4). After $4 \mathrm{~h}$, concentrations decreased to $<0.5 \mu \mathrm{g} / \mathrm{g}$ were found in 1 cow at $48 \mathrm{~h}$ and $52 \mathrm{~h}$ to $72 \mathrm{~h}$ after $\mathrm{C} 1$, and in another cow at $48 \mathrm{~h}$ after C1 (Table 1). 


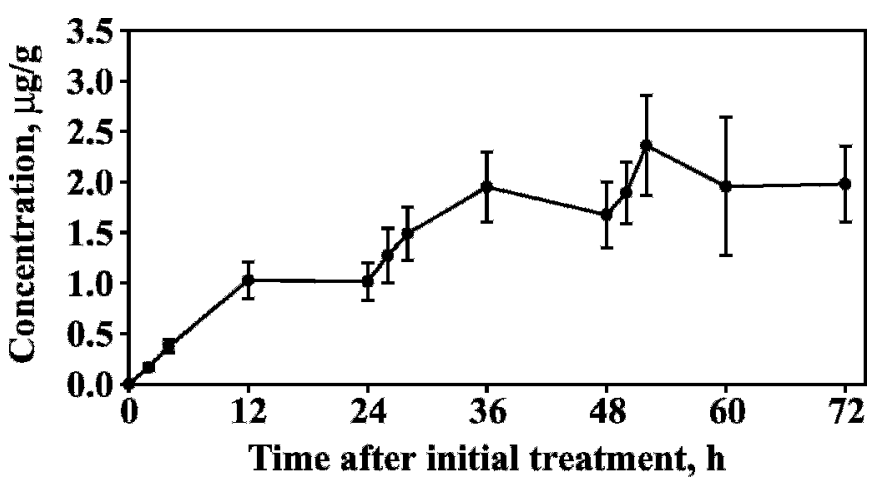

Figure 3. Mean concentrations ( \pm SEM) of desfuroylceftiofuracetamide in caruncular tissue after 3 subcutaneous administrations of 1 $\mathrm{mg}$ of ceftiofur equivalents/kg of BW of ceftiofur hydrochloride sterile suspension at 0,24 , and $48 \mathrm{~h}$.

\section{Lochia}

In 1 cow, lochia could not be obtained at 48 and 72 $\mathrm{h}$ after $\mathrm{C} 1$. Mean concentration of DCA exceeded threshold values of $0.125 \mu \mathrm{g} / \mathrm{mL}$ at $2 \mathrm{~h}$ and of $0.5 \mu \mathrm{g} / \mathrm{mL}$ at $12 \mathrm{~h}$. Mean concentration remained $>0.5 \mu \mathrm{g} / \mathrm{mL}$ until the end of the observation period (Figure 5). A maximum in mean concentrations was reached at $12 \mathrm{~h}(0.87$ $\mu \mathrm{g} / \mathrm{mL}), 2 \mathrm{~h}(1.32 \mu \mathrm{g} / \mathrm{mL})$, and $4 \mathrm{~h}(2.33 \mu \mathrm{g} / \mathrm{mL})$ after $\mathrm{C} 1, \mathrm{C} 2$, and C3, respectively (Figure 5). At none of the sampling points, however, did all cows reach concentrations $>0.5 \mu \mathrm{g} / \mathrm{mL}$. Concentrations $<0.125 \mu \mathrm{g} / \mathrm{mL}$ were found after $2 \mathrm{~h}$ in 4 samples (Table 1 ).

\section{Temperature}

Mean rectal temperatures are shown in Figure 6. After an initial increase at $4 \mathrm{~h}\left(39.3^{\circ} \mathrm{C}\right)$, temperature declined moderately to $38.9^{\circ} \mathrm{C}$ at $24 \mathrm{~h}$. Thereafter, mean

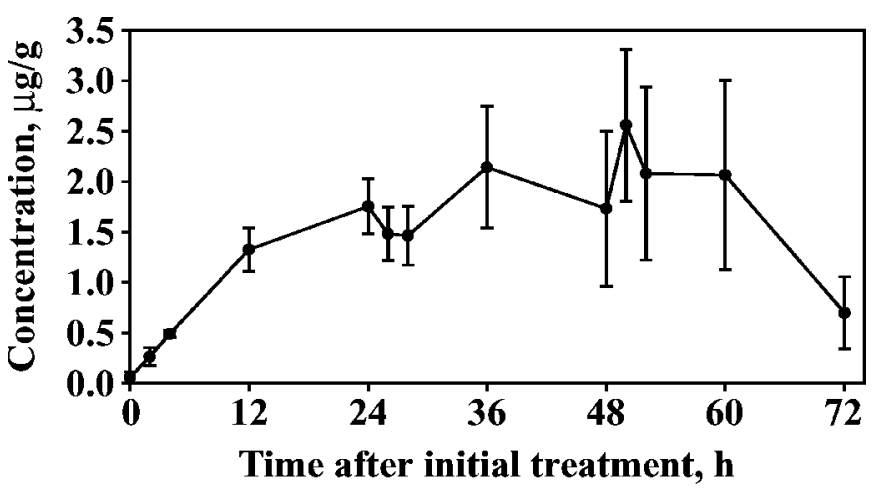

Figure 4. Mean concentrations ( \pm SEM) of desfuroylceftiofuracetamide in cotyledonal tissue after 3 subcutaneous administrations of $1 \mathrm{mg}$ of ceftiofur equivalents/kg of BW of ceftiofur hydrochloride sterile suspension at 0,24 , and $48 \mathrm{~h}$.

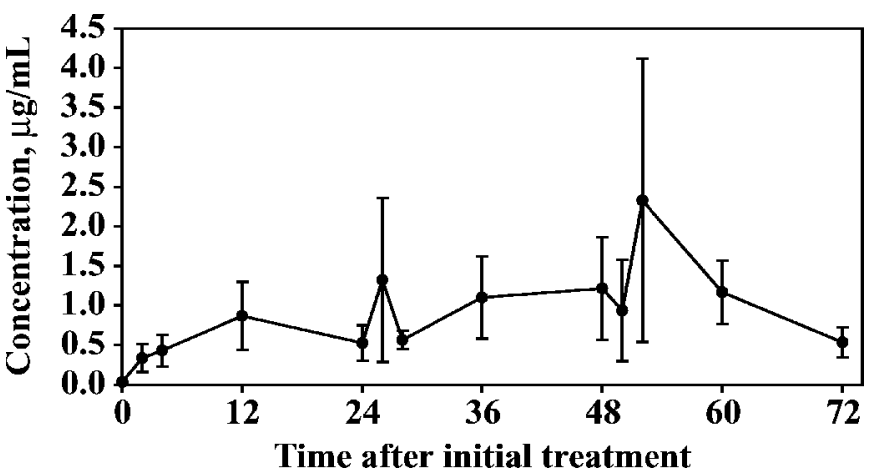

Figure 5. Mean concentrations ( \pm SEM) of desfuroylceftiofuracetamide in lochia after 3 subcutaneous administrations of $1 \mathrm{mg}$ of ceftiofur equivalents $/ \mathrm{kg}$ of BW of ceftiofur hydrochloride sterile suspension at 0,24 , and $48 \mathrm{~h}$.

temperatures increased to a maximum of $40.1^{\circ} \mathrm{C}$ at 52 $\mathrm{h}$ and decreased to a mean rectal temperature of $39.3^{\circ} \mathrm{C}$ at the end of the observation period.

\section{Correlations}

A significant positive correlation of time after the first of 3 injections was found with concentrations of DCA in uterine tissues, cotyledons, and lochia, but not of time with concentration of DCA in serum. Correlations of rectal temperature with concentration of DCA in serum, endometrial, and caruncular tissues, and in lochia, also were positive, but not of temperature with concentration of DCA in cotyledonal tissue. Correlations of concentrations of DCA in serum with concentrations in uterine tissues and cotyledons were positive, but not with concentrations in lochia (Table 2).

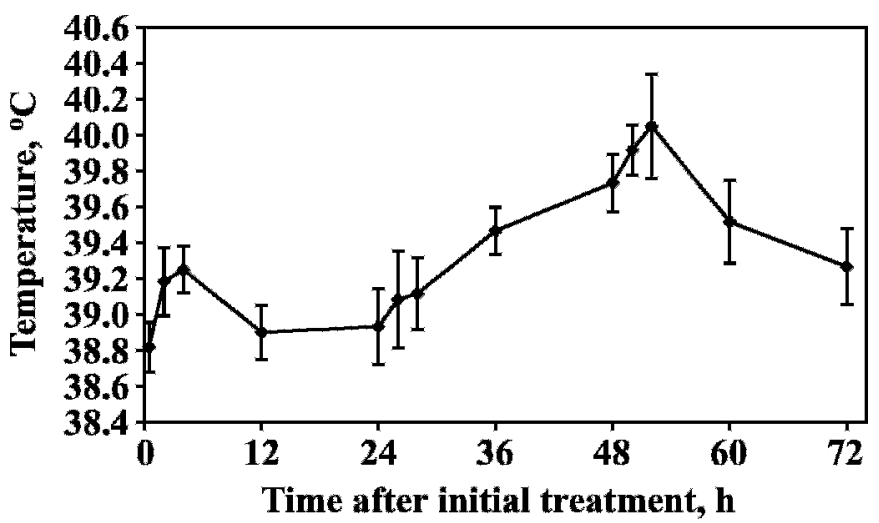

Figure 6. Mean temperatures $( \pm$ SEM) after 3 subcutaneous administrations of $1 \mathrm{mg}$ of ceftiofur equivalents $/ \mathrm{kg}$ of $\mathrm{BW}$ of ceftiofur hydrochloride sterile suspension at 0,24 , and $48 \mathrm{~h}$. 
Table 2. Correlations of time after the first treatment with ceftiofur hydrochloride, rectal temperature, and concentrations of desfuroylceftiofuracetamide (DCA) in serum with concentrations of DCA in serum, endometrium, caruncles, cotyledons, and lochia after 3 subcutaneous administrations (24 h apart) of $1 \mathrm{mg}$ of ceftiofur equivalents per kg of BW as ceftiofur hydrochloride sterile suspension

\begin{tabular}{lccccc}
\hline Item & Serum & Endometrium & Caruncles & Cotyledons & Lochia \\
\hline No. of samples & 72 & 70 & 71 & 68 & 66 \\
Time after initial injection & 0.19 & $0.38^{*}$ & $0.64^{*}$ & $0.30^{*}$ & $0.29^{*}$ \\
Temperature & $0.30^{*}$ & $0.30^{*}$ & $0.42^{*}$ & 0.18 & $0.28^{*}$ \\
Serum & 1.00 & $0.50^{*}$ & $0.44^{*}$ & $0.27^{*}$ & -0.11 \\
\hline
\end{tabular}

$* P<0.05$.

\section{DISCUSSION}

The objective of the present study was to determine concentrations of ceftiofur derivatives in serum, endometrium, caruncles, cotyledons, and lochia of cows having RFM after 3 subcutaneous injections with $1 \mathrm{mg}$ of ceftiofur equivalents/kg of BW as ceftiofur hydrochloride sterile suspension. This is the first study describing pharmacokinetics of ceftiofur hydrochloride in cows treated for RFM.

Pharmacokinetics of ceftiofur have been described for several animals, including cattle (Brown et al., 2000; Okker et al., 2002), pigs (Brown et al., 1999), mares (Jonker, 1997), sheep (Craigmill et al., 1997), goats (Courtin et al., 1997), and llama and alpaca (Drew et al., 2004). In most reports, however, pharmacokinetics were determined for ceftiofur in plasma. Only in a few studies were concentrations of ceftiofur examined in uterine tissues. After intramuscular administration of $2 \mathrm{mg} / \mathrm{kg}$ of ceftiofur to 4 mares, Jonker (1997) found mean concentrations of $1.23 \mu \mathrm{g} / \mathrm{g}$ of DCA in endometrial tissue. Okker et al. (2002) have demonstrated that subcutaneous administration of $1 \mathrm{mg} / \mathrm{kg}$ of BW of ceftiofur hydrochloride to 4 healthy postpartum cows resulted in mean concentrations of ceftiofur derivatives in plasma and uterine tissues that exceed reported $\mathrm{MIC}_{90}$ value of $0.5 \mu \mathrm{g} / \mathrm{mL}$ for $E$. coli and of $0.125 \mu \mathrm{g} / \mathrm{mL}$ for $A$. pyogenes, $F$. necrophorum, and $P$. melaninogenicus (Salmon et al., 1996; Sheldon et al., 2004). The predominant bacterial pathogen for acute metritis is $E$. coli, and therefore, the focus of this discussion is on the threshold value of $0.5 \mu \mathrm{g} / \mathrm{mL}$. The threshold value of $0.125 \mu \mathrm{g} / \mathrm{mL}$, however, which is relevant for A. pyogenes, $F$. necrophorum, and $P$. melaninogenicus, was exceeded in all tissues at $2 \mathrm{~h}$. Mean concentrations remained greater than this value for the entire observation period.

In the present study, increased mean concentration of ceftiofur derivatives in serum to a first maximum was comparable with observations of Okker et al. (2002), who found a maximum of $2.85 \mu \mathrm{g} / \mathrm{mL}$ in plasma $2 \mathrm{~h}$ after administration. Mean concentrations of ceftiofur derivatives exceeded $0.5 \mu \mathrm{g} / \mathrm{g}$ in uterine tissues and cotyledons by $4 \mathrm{~h}$ (endometrium) and $12 \mathrm{~h}$ (caruncles and cotyledons), respectively, after the initial treatment. The increase of concentrations in endometrial and caruncular tissues was similar to findings of Okker et al. (2002), who described peaks at $5 \mathrm{~h}$ (endometrium) and $11.5 \mathrm{~h}$ (caruncles) after treatment. In endometrial tissue, however, first maximum concentration of 1.35 $\mu \mathrm{g} / \mathrm{g}$ was $<2.25 \mu \mathrm{g} / \mathrm{g}$ reported by Okker et al. (2002). For clinical efficacy of this treatment, it might be of interest that concentrations of ceftiofur derivatives in endometrium and caruncles increased to a maximum (2.02 and $2.36 \mu \mathrm{g} / \mathrm{g}$, respectively) after the third daily injection.

Mean concentrations of ceftiofur derivatives in serum, uterine tissues, and cotyledons remained greater than reported MIC $_{90}$ values for common uterine pathogens of $0.5 \mu \mathrm{g} / \mathrm{mL}$ (Sheldon et al., 2004) during the entire observation period. In single samples, however, mainly immediately before the second and third injection of ceftiofur hydrochloride, concentrations decreased to $<0.5 \mu \mathrm{g} / \mathrm{mL}$. Thus, in few instances, suboptimal concentrations during the recommended treatment period of $5 \mathrm{~d}$ might occur. It is not possible to describe the duration of concentrations below $0.5 \mu \mathrm{g} / \mathrm{mL}$ because samples were collected at 12 and $24 \mathrm{~h}$ after each injection. Also, it is not clear whether this finding of suboptimal concentrations in our study is practically or pharmacologically relevant.

Tissue concentrations of $\beta$-lactams are known to underestimate drug concentrations in the extracellular fluid. When tissues are homogenized for analysis the intracellular fluid is liberated and dilutes the extracellular fluid. This is especially true for $\beta$-lactams that do not penetrate cells very well because of their limited lipid solubility (Brown et al., 1995). Further research is required to evaluate whether implementing a shorter interval between injections or using a larger dose of $2.2 \mathrm{mg}$ of ceftiofur hydrochloride/kg of BW, which is approved in the United States, would result in different pharmacokinetic patterns.

For lochia, results were more heterogeneous. After the initial daily injection with ceftiofur, the increase of 
mean concentration was similar to those reported by Okker et al. (2002), who found a maximum of $0.98 \mu \mathrm{g} /$ $\mathrm{mL}$ at $5 \mathrm{~h}$. After the second daily injection of ceftiofur hydrochloride, concentrations were very inconsistent among cows. At all collection periods, concentrations of ceftiofur derivatives were $<0.5 \mu \mathrm{g} / \mathrm{mL}$ in some cows. This might be explained by variable amounts of lochia in the uterine cavity and by unknown interactions of ceftiofur binding to organic debris. It is questionable whether elevated concentrations of ceftiofur in lochia are essential for effective treatment. It is probably more important to achieve effective concentrations in uterine tissues at the site of inflammation and infection.

In serum, uterine tissues, cotyledons, and lochia, concentrations of ceftiofur derivatives showed a wave-like pattern with reduced concentrations $24 \mathrm{~h}$ after each injection of ceftiofur hydrochloride. In uterine tissues, cotyledons, and lochia, concentrations increased during the observation period. This indicates an accumulation of ceftiofur derivatives in inflamed tissues in cows with RFM. This confirms results of Clarke et al. (1996) who found greater concentrations of ceftiofur in implanted tissue chambers in calves inoculated with Pasteurella haemolytica than in noninfected chambers. The study by Okker et al. (2002) was performed on healthy cows over a period of $24 \mathrm{~h}$ after a single injection of ceftiofur hydrochloride. Therefore, it is not clear whether this accumulation is specific to cows with uterine infections or also prevalent in healthy cows.

Several plausible interpretations exist for the positive correlation of rectal temperature with concentrations of ceftiofur derivatives in serum, endometrial, and caruncular tissues. One is that temperature increased during the study period because of intrauterine manipulations. This hypothesis is confirmed by an increased temperature 2 and $4 \mathrm{~h}$ after sampling. A second explanation is that with elevated concentration of ceftiofur derivatives in serum and uterine tissues, the bactericide potential of the antimicrobial increases and releases bacterial and probably pyretic toxins. A third interpretation is that the increase of temperature is independent from sampling and concentrations of ceftiofur derivatives and occurs to a large extent in cows having RFM regardless of an antimicrobial therapy. Increased rectal temperature has been described for RFM cows treated systemically with ceftiofur hydrochloride as well as for cows treated with intrauterine antibiotics (Drillich et al., 2006a,b). In another study by Risco and Hernandez (2003), however, treatment of RFM cows with $2.2 \mathrm{mg}$ of ceftiofur/ $\mathrm{kg}$ of BW was beneficial for prevention of metritis (i.e., fever and fetid discharge).

This study demonstrated that in cows with RFM, mean concentrations of ceftiofur derivatives exceeded reported $\mathrm{MIC}_{90}$ values for $E$. coli, a common uterine pathogen in serum and endometrium by 2 and $4 \mathrm{~h}$, respectively, in caruncular and cotyledonal tissue, and in lochia by $12 \mathrm{~h}$ after injecting $1 \mathrm{mg}$ of ceftiofur equivalents/kg of BW as ceftiofur hydrochloride sterile suspension. Mean concentrations exceeded $\mathrm{MIC}_{90}$ values for $A$. pyogenes, $F$. necrophorum, and $P$. melaninogenicus in all tissues by $2 \mathrm{~h}$. After a second and third daily injection of ceftiofur hydrochloride, mean concentrations of ceftiofur derivatives did not decrease below $\mathrm{MIC}_{90}$ values until after the end of the study period of $72 \mathrm{~h}$. Only in single samples, especially $24 \mathrm{~h}$ after treatment, did concentrations decrease temporarily below $\mathrm{MIC}_{90}$ values.

\section{ACKNOWLEDGMENTS}

Ceftiofur sodium ( $898 \mathrm{mg} / \mathrm{g}$ of active substance) for HPLC analysis was a kind gift from Pfizer Animal Health, Puurs, Belgium.

\section{REFERENCES}

Brown, S. A., S. T. Chester, A. K. Speedy, V. L. Hubbard, J. K. Callahan, P. J. Hamlow, B. Hibbard, and E. J. Robb. 2000. Comparison of plasma pharmacokinetics and bioequivalence of ceftiofur sodium in cattle after a single intramuscular or subcutaneous injection. J. Vet. Pharmacol. Ther. 23:273-280.

Brown, S. A., N. L. DeLeeuw, G. L. Stahl, and R. D. Roof. 1995. Concentrations of ceftiofur and metabolites in mouse lung perfused or non perfused in situ compared to tilmicosin. J. Vet. Pharmacol. Ther. 18:385-387.

Brown, S. A., B. J. Hanson, A. Mignot, L. Millerioux, P. J. Hamlow, V. L. Hubbard, J. K. Callahan, and F. M. Kausche. 1999. Comparison of plasma pharmacokinetics and bioavailability of ceftiofur sodium and ceftiofur hydrochloride in pigs after a single intramuscular injection. J. Vet. Pharmacol. Ther. 22:35-40.

Cervantes, C. C., M. P. Brown, R. Gronwall, and K. Merritt. 1993. Pharmacokinetics and concentrations of ceftiofur sodium in body fluids and endometrium after repeated intramuscular injections in mares. Am. J. Vet. Res. 54:573-575.

Chenault, J. R., J. F. McAllister, S. T. J. Chester, K. J. Dame, F. M. Kausche, and E. J. Robb. 2004. Efficacy of ceftiofur hydrochloride sterile suspension administered parenterally for the treatment of acute postpartum metritis in dairy cows. J. Am. Vet. Med. Assoc. 224:1634-1639.

Clarke, C. R., S. A. Brown, R. N. Streeter, J. M. Clarke, P. J. Hamlow, J. K. Callahan, V. L. Hubbard, A. K. Speedy, and G. E. Burrows. 1996. Penetration of parenterally administered ceftiofur into sterile vs. Pasteurella haemolytica-infected tissue chambers in cattle. J. Vet. Pharmacol. Ther. 19:376-381.

Courtin, F., A. L. Craigmill, S. E. Wetzlich, C. R. Gustafson, and T. S. Arndt. 1997. Pharmacokinetics of ceftiofur and metabolites after single intravenous and intramuscular administration and multiple intramuscular administrations of ceftiofur sodium to dairy goats. J. Vet. Pharmacol. Ther. 20:368-373.

Craigmill, A. L., S. A. Brown, S. E. Wetzlich, C. R. Gustafson, and T. S. Arndt. 1997. Pharmacokinetics of ceftiofur and metabolites after single intravenous and intramuscular administration and multiple intramuscular administrations of ceftiofur sodium to sheep. J. Vet. Pharmacol. Ther. 20:139-144.

Drew, M. L., L. Johnson, D. Pugh, C. B. Navarre, I. T. Taylor, and A. L. Craigmill. 2004. Pharmacokinetics of ceftiofur in llamas and alpacas. J. Vet. Pharmacol. Ther. 27:13-20. 
Drillich, M., O. Beetz, A. Pfutzner, M. Sabin, H. J. Sabin, P. Kutzer, H. Nattermann, and W. Heuwieser. 2001. Evaluation of a systemic antibiotic treatment of toxic puerperal metritis in dairy cows. J. Dairy Sci. 84:2010-2017.

Drillich, M., M. Mahlstedt, U. Reichert, B. A. Tenhagen, and W. Heuwieser. 2006a. Strategies to improve the therapy of retained fetal membranes in dairy cows. J. Dairy Sci. 89:627-635.

Drillich, M., A. Pfutzner, H. J. Sabin, M. Sabin, and W. Heuwieser. 2003. Comparison of two protocols for the treatment of retained fetal membranes in dairy cattle. Theriogenology 59:951-960.

Drillich, M., U. Reichert, M. Mahlstedt, and W. Heuwieser. 2006b. Comparison of two strategies for a systemic antibiotic treatment of dairy cows with retained fetal membranes: Preventive vs. selective treatment. J. Dairy Sci. 89:1502-1508.

Hornish, R. E., and S. F. Kotarski. 2002. Cephalosporins in veterinary medicine-Ceftiofur use in food animals. Curr. Top. Med. Chem. 2:717-731.

Jonker, F. H. 1997. Secretion of ceftiofur in equine endometrium after parenteral administration. J. Vet. Pharmacol. Ther. 20(Suppl.):37.

Okker, H., E. J. Schmitt, P. L. Vos, P. Scherpenisse, A. A. Bergenwerff, and F. H. Jonker. 2002. Pharmacokinetics of ceftiofur in plasma and uterine secretions and tissues after subcutaneous postpartum administration in lactating diary cows. J. Vet. Pharmacol. Ther. 25:33-38.
Olson, S. C., M. G. Beconi-Barker, E. B. Smith, R. A. Martin, T. J. Vidmar, and L. D. Adams. 1998. In vitro metabolism of ceftiofur in bovine tissues. J. Vet. Pharmacol. Ther. 21:112-120.

Risco, C. A., and J. Hernandez. 2003. Comparison of ceftiofur hydrochloride and estradiol cyrpionat for metritis prevention and reproductive performance in dairy cows affected with retained fetal membranes. Theriogenology 60:47-58.

Salmon, S. A., J. L. Watts, and R. J. Yancey. 1996. In vitro activity of ceftiofur and its primary metabolite, desfuroylceftiofur, against organisms of veterinary importance. J. Vet. Diagn. Invest. 8:332-336.

Sheldon, I. M., M. Bushnell, J. Montgomery, and A. N. Rycroft. 2004. Minimum inhibitory concentrations of some antimicrobial drugs against bacteria causing uterine infections in cattle. Vet. Rec. 155:383-387.

Sheldon, I. M., and H. Dobson. 2004. Postpartum uterine health in cattle. Anim. Reprod. Sci. 82-83:295-306.

Smith, B. I., G. A. Donovan, C. Risco, R. Littell, C. Young, L. H. Stanker, and J. Elliott. 1998. Comparison of various antibiotic treatments for cows diagnosed with toxic puerperal metritis. J. Dairy Sci. 81:1555-1562.

Zhou, C., J. F. Boucher, K. J. Dame, M. Moreira, R. Graham, J. Nantel, S. Zuidhof, L. Arfi, R. Flores, G. Neubauer, and J. Olson. 2001. Multilocation trial of ceftiofur for treatment of postpartum cows with fever. J. Am. Vet. Med. Assoc. 219:805-808. 